\title{
PERAN MEDIASI MOTIVASI KERJA ATAS KEPEMIMPINAN TRANSFORMASIONAL TERHADAP KINERJA PEGAWAI (STUDI PADA PEGAWAI PT. MNC SKYVISION TBK. CABANG SURABAYA)
}

\author{
Rini Novianti \\ Sekolah Tinggi Ilmu Ekonomi "Urip Sumoharjo" Surabaya \\ rini.nouve@gmail.com
}

\begin{abstract}
ABSTRAK
Penelitian ini bertujuan untuk mengetahui : (1) pengaruh kepemimpinan transformasional terhadap motivasi kerja, (2) pengaruh kepemimpinan transformasional terhadap kinerja pegawai, (3) pengaruh motivasi kerja terhadap kinerja pegawai. Populasi dalam penelitian ini adalah pegawai PT. MNC Skyvision Tbk. Cabang Surabaya yang berjumlah 174 orang. Teknik pengambilan sampel dengan menggunakan simple random sampling sehingga didapatkan jumlah sampel 121 orang. Pengumpulan data menggunakan kuesioner. Analisis data dilakukan dengan menggunakan analisis jalur. Hasil penelitian menunjukkan bahwa kepemimpinan transformasional berpengaruh signifikan terhadap motivasi kerja, kepemimpinan transformasional berpengaruh signifikan terhadap kinerja pegawai, motivasi kerja berpengaruh signifikan terhadap kinerja pegawai. Motivasi kerja memediasi hubungan antara kepemimpinan transformasional dan kinerja pegawai sebesar 0.398. Hal ini berarti penerapan kepemimpinan transformasional yang baik akan mampu meningkatkan motivasi kerja pegawai untuk bekerja lebih baik sehingga dampaknya adalah akan terjadi peningkatan kinerja pegawai yang tentunya sangat diharapkan oleh perusahaan.
\end{abstract}

Kata kunci : kepemimpinan transformasional, motivasi kerja, kinerja pegawai

\section{PENDAHULUAN}

Pada era persaingan global yang semakin kompetitif saat ini, agar tetap bertahan maka perusahaan dituntut untuk mempunyai kinerja perusahaan yang terus meningkat. Langkah utama yang dapat dilakukan oleh perusahaan yakni dengan meningkatkan kinerja pegawai melalui pengelolaan Sumber Daya Manusia yang baik sehingga akan memberikan nilai tambah yang menjadikan perusahaan mempunyai daya saing yang unggul. Perusahan berusaha meningkatkan kinerja pegawai melalui pembenahan atau peningkatan faktorfaktor yang mempengaruhinya, terutama kepemimpinan karena setiap hari berinteraksi dengan pegawai saat bekerja.

Model kepemimpinan mutakhir seperti kepemimpinan transformasional pada perusahaan akan memainkan 
peranan yang penting bagi perusahaan. Kepemimpinan transformasional menurut Robbins dan Judge (2014:90) merupakan gaya pemimpin dalam menginspirasi bawahan melalui kemampuan mempengaruhi yang luar biasa sehingga bawahan bersedia fokus bekerja melebihi kepentingan pribadi. Kepemimpinan transformasional dapat meningkatkan kepercayaan atau keyakinan diri pegawai yang mengakibatkan terjadinya perubahanperubahan positif pada diri pegawai yang pada akhirnya diharapkan dapat meningkatkan produktivitas dan kinerja pegawai.

Selain kepemimpinan transformasional, motivasi juga menjadi hal yang penting dalam upaya meningkatkan kinerja pegawai. Mangkunegara (2009:93) menjelaskan bahwa motif merupakan suatu dorongan kebutuhan dalam diri pegawai yang perlu dipenuhi agar pegawai tersebut dapat menyelesaikan tugas-tugas yang dibebankan kepadanya dengan baik. Salah satu teori motivasi yang terkait dengan kebutuhan individu adalah teori ERG yang dikemukakan oleh Clayton Adelfer yang merupakan penyederhanaan dari teori Maslow, dimana seseorang akan bekerja dengan baik untuk memenuhi dorongan yang ada dalam dirinya yakni berupa kebutuhan. Dalam teori ini kebutuhan yang lebih mendasar harus terpenuhi terlebih dahulu sebelum seseorang memenuhi kebutuhan yang lebih tinggi. Betapa pentingnya motivasi kerja membuat pihak-pihak yang berkepentingan dan bertanggungjawab dalam keberhasilan perusahaan perlu memperhatikan motivasi kerja pegawai yang mengarah kepada peningkatan kinerja pegawai.

Penelitian ini fokus pada pegawai PT. MNC Skyvision Tbk. Cabang Surabaya. PT. MNC Skyvision Tbk. Cabang Surabaya letaknya cukup strategis berada di J1. Ngagel Jaya No.11 Surabaya. Setiap kantor cabang PT. MNC Skyvision Tbk. dipimpin oleh seorang kepala cabang. Pemimpin mempunyai tugas dan wewenang untuk mengelola dan mengembangkan sumber daya manusia yang ada di kantor cabang tersebut demi tercapainya tujuan perusahaan melalui peningkatan kinerja pegawai dengan membina hubungan baik antar sesama pegawai, meningkatkan motivasi kerja pegawai, meningkatkan kompetensi yang dimiliki pegawai, dsb. Semua tugas dan wewenang tersebut dilakukan dengan 
menerapkan kepemimpinan transformasional.

Banyak penelitian yang menunjukkan bahwa kepemimpinan transformasional dan motivasi kerja memiliki pengaruh terhadap kinerja pegawai. Seperti penelitian yang telah dilakukan oleh Wijanarko (2014): Marisatul Kiptiyah (2015), Reppie Adnyani (2015), Prakoso, dkk (2014), dan Indra Kharis (2015).

Berdasarkan penjelasan latar belakang tersebut, maka rumusan masalah yang diajukan dalam penelitian ini adalah : (1) apakah kepemimpinan transformasional berpengaruh signifikan terhadap motivasi kerja ?, (2) apakah kepemimpinan transformasional berpengaruh signifikan terhadap kinerja pegawai ?, (3) apakah motivasi kerja berpengaruh signifikan terhadap kinerja pegawai ?.

\section{TINJAUAN PUSTAKA}

\subsection{Kinerja Pegawai}

Kinerja adalah pencapaian hasil kerja pegawai berdasarkan persyaratanpersyaratan pekerjaan yang melekat padanya (Bangun, 2012:229). Sedangkan menurut Mangkunegara (2013:67) kinerja adalah hasil kerja yang dicapai pegawai secara kualitas ataupun kuantitas sesuai dengan tanggungjawab yang diberikan kepadanya. Berdasarkan beberapa definisi tersebut, dapat disimpulkan bahwa kinerja adalah hasil kerja pegawai baik secara kuantitas ataupun kualitas sesuai dengan tanggungjawab dan perannya dalam perusahaan.

Budiharjo (2015:4) membagi mnfaat penilaian kinerja pegawai dalam dua klasifikasi yakni manfaat penilaian kinerja bagi pegawai dan bagi perusahaan. Bagi pegawai penilaian kinerja bermanfaat dalam memicu semangat berkompetisi secara positif antar pegawai, meningkatkan etos kerja, dan meningkatkan produktivitas yang ujungnya adalah peningkatan kinerja. Sedangkan bagi perusahaan penilaian kinerja pegawai bermanfaat dalam mengenal talenta kerja pegawai sebagai dasar bagi perusahaan dalam menempatkan pegawai pada posisi yang tepat, kaderisasi pimpinan, menstimulasi produktivitas pegawai yang nantinya berdampak pada peningkatan kinerja perusahaan.

Bangun (2012;233) mengukur kinerja pegawai berdasarkan dimensi sebagai berikut :

1. Kuantitas yakni jumlah pekerjaan yang dihasilkan individu atau 
kelompok sesuai persyaratan yang menjadi standar pekerjaan.

2. Kualitas : persyaratan mutu yang harus dipenuhi dalam melaksanakan pekerjaan tertentu.

3. Ketepatan waktu : persyaratan waktu yang harus dipenuhi dalam menyelesaikan pekerjaan tertentu, terutama pekerjaan yang dalam penyelesaiannya memiliki ketergantungan terhadap pekerjaan lainnya.

4. Kehadiran : jumlah kehadiran pegawai di tempat kerja untuk menyelesaikan pekerjaan sesuai waktu kerja yang telah ditentukan.

5. Kemampuan kerjasama : kemampuan untuk bekerjasama dengan orang lain dalam suatu tim, ataupun dengan unit kerja lainnya.

\subsection{Kepemimpinan Transforma- sional}

Kepemimpinan transformasional menurut Robbins dan Judge (2014:90) merupakan gaya pemimpin dalam menginspirasi bawahan melalui kemampuan mempengaruhi yang luar biasa sehingga bawahan bersedia fokus bekerja melebihi kepentingan pribadi. Sedangkan Wibowo (2013:285) mengemukakan bahwa kepemimpinan transformasional adalah perspektif kepemimpinan yang menciptakan, mengkomunikasikan, membuat model visi untuk organisasi, dan memberikan inspirasi kepada bawahan untuk berusaha menampakkan kinerja lebih baik sehingga secara global akan mengubah kinerja tim atau organisasi untuk pencapaian visi tersebut.

Dari beberapa definisi tersebut dapat diintisarikan bahwa kepemimpinan transformasional merupakan gaya kepemimpinan yang mempengaruhi bawahan agar bersedia bekerja melebihi kepentingan pribadi dengan memberikan motivasi, menginspirasi, serta menciptakan dan mengkomunikasikan model visi organisasi sehingga bawahan menampakkan kinerja yang optimal dimana nantinya juga berdampak terhadap kinerja perusahaan. Kepemimpinan transformasional mengarahkan organisasi kepada perubahan yang lebih baik sehingga lebih sesuai dengan lingkungan sekitarnya.

Pelaksanaan kepemimpinan transformasional dapat diukur dengan beberapa indikator yang terdapat dalam diri pegawai antara lain : meningkatnya percaya diri dalam diri pegawai, implementasi visi, kreatifitas, nyaman 
bekerja dengan atasan, meningkatkan potensi diri, motivasi bawahan, dan atasan memberikan perhatian secara pribadi (Mariam 2009:51-59) dan Kiptiyah (2015:25).

\subsection{Motivasi Kerja}

Motivasi kerja sangat penting dalam menjaga kinerja pegawai dan sering dikatakan sebagai kunci kinerja. Motivasi kerja pegawai yang terpelihara dengan baik akan mampu meningkatkan kinerja pegawai melalui kesediaan pegawai untuk bekerja dengan baik, meningkatkan keahlian dalam melaksanakan tugas dan persepsi peran positif dalam benak pegawai.

Teori motivasi kerja yang digunakan dalam penelitian ini adalah teori motivasi ERG yang dikemukakan oleh Clayton Adelfer. Teori ERG merupakan penyederhanaan dari teori motivasi Maslow yakni membagi kebutuhan setiap orang dengan tiga hirarki kebutuhan yang harus dipenuhi antara lain kebutuhan dasar (existence), keterhubungan (relatedness), dan pertumbuhan (growth) (Robbins, 2008 :221).

Sedangkan menurut Mangkunegara (2009:98) pengukuran teori ERG yang dikemukakan oleh
Clayton Adelfer dijabarkan sebagai berikut :

1. Existence Needs (eksistensi). Kebutuhan ini berhubungan dengan kebutuhan fisik pegawai yang harus terpenuhi seperti kebutuhan makan dan fasilitas makan, waktu istirahat, BAK, BAB, bersih diri, kebutuhan mendapatkan gaji, serta kebutuhan akan rasa aman dalam bekerja.

2. Relatedness Needs (keterhubungan). Kebutuhan ini merupakan kepuasan dalam berinteraksi dalam lingkungan kerja, seperti kebutuhan interaksi antar pribadi, hubungan yang harmonis dengan rekan kerja, serta hubungan yang harmonis dengan pimpinan.

3. Growth Needs (pertumbuhan). Kebutuhan ini merupakan kebutuhan untuk mengembangkan dan meningkatkan kemampuan pribadi terutama dalam bekerja seperti terpenuhinya kebutuhan untuk mengembangkan kompetensi yang dimiliki dengan maksimal, kesempatan untuk mengembangkan kompetensi baru, pemanfaatan secara penuh kompetensi yang dimiliki pegawai oleh perusahaan, serta kebebasan bagi pegawai untuk mengungkapkan ide dan 
mengaplikasikan kreatifitas pada pekerjaannya.

\subsection{Hipotesis}

$\mathrm{H}_{1}$ : kepemimpinan transformasional berpengaruh signifikan terhadap motivasi kerja

$\mathrm{H}_{2}$ : Kepemimpinan transformasional berpengaruh signifikan terhadap kinerja pegawai

$\mathrm{H}_{3}$ : Motivasi kerja berpengaruh signifikan terhadap kinerja pegawai.

\section{METODOLOGI PENELITIAN}

\subsection{Desain Penelitian}

Penelitian ini merupakan jenis penelitian explanatory research dengan pendekatan kuantitatif. Penelitian explanatory research adalah bertujuan untuk menelaah hubungan kausal antar variabel-variabel melalui pengujian hipotesis yang telah ditetapkan sebelumnya. Pendekatan kuantitatif yang dimaksud adalah metode mengolah data untuk menggambarkan keadaan perusahaan yang kemudian dianalisis berdasarkan data yang ada tanpa memanipulasi variabel dan tanpa menciptakan kondisi tertentu.

\subsection{Tempat dan Waktu Penelitian}

Penelitian dilakukan di PT. MNC Skyvision Tbk. Cabang Surabaya yang berlokasi di Jl. Ngagel Jaya No.11 Surabaya. Waktu pelaksanaan penelitian pada Januari 2017.

\subsection{Populasi dan Sampel}

Populasi adalah wilayah generalisasi yang terdiri atas obyek/subyek yang mempunyai kuantitas dan karakteristik tertentu yang ditetapkan oleh peneliti untuk dipelajari dan kemudian ditarik kesimpulannya (Sugiyono, 2015 : 148). Populasi dalam penelitian ini adalah seluruh pegawai PT. MNC Skyvision Tbk. Cabang Surabaya yang berjumlah 174 orang.

Sampel adalah bagian dari jumlah dan karakteristik yang dimiliki oleh populasi tersebut (Sugiyono, 2015 : 149). Sampel dalam penelitian ini adalah pegawai PT. MNC Skyvision Tbk. Cabang Surabaya yang berjumlah 121 orang. Pengambilan sampel dalam penelitian ini menggunakan metode simple random sampling yakni pengambilan anggota sampel dari populasi yang dilakukan secara acak tanpa memperhatikan strata yang ada dalam populasi tersebut. Adapun 
penentuan ukuran sampel menggunakan rumus Slovin.

\subsection{Metode Pengumpulan Data}

Penelitian ini menggunakan instrument kuesioner dengan skala likert, dimana setiap responden diminta pendapatnya mengenai suatu pernyataan dengan skala penilaian dari satu (1) hingga lima (5). Jawaban yang paling mendukung pernyataan diberikan skor yang tinggi sedangkan jawaban yang tidak mendukung pernyataan diberikan skor rendah. Pernyataan dalam kuesioner menerangkan tanggapan responden terhadap variabel kepemimpinan transformasional, motivasi kerja, dan kinerja pegawai.

\subsection{Variabel Penelitian dan Definisi Operasional Variabel}

Variabel

kepemimpinan

transformasional (X). Kepemimpinan transformasional adalah perspektif kepemimpinan yang mempengaruhi bawahan agar mau bekerja melebihi kepentingan pribadi dengan memberikan motivasi, menginspirasi, serta menciptakan dan mengkomunikasikan model visi organisasi sehingga pegawai menampakkan kinerja yang optimal selama bekerja di PT. MNC Skyvision
Tbk. Cabang Surabaya. Indikator untuk mengukur kepemimpinan transformasional menurut Mariam (2009) dan Marisatul Kiptiyah (2015) antara lain meningkatkan percaya diri, implementasi visi, kreatifitas, nyaman bekerja dengan atasan, meningkatkan potensi diri, motivasi bawahan, dan perhatian secara pribadi.

Variabel motivasi kerja (Y1). Motivasi kerja adalah daya pendorong yang mengakibatkan pegawai mau dan rela untuk mengerahkan kemampuan dalam bentuk keahlian atau keterampilan, tenaga dan waktunya untuk menyelenggarakan berbagai kegiatan yang menjadi tanggungjawabnya dan menunaikan kewajibannya dalam rangka pencapaian tujuan dan berbagai sasaran perusahaan. Indikator untuk mengukur motivasi kerja menggunakan teori ERG antara lain existence needs (eksistensi), relatedness needs (keterhubungan), dan growth needs (pertumbuhan).

Variabel kinerja pegawai (Y2). Kinerja pegawai adalah hasil kerja pegawai PT.MNC Skyvision Tbk. Cabang Surabaya baik secara kuantitas ataupun kualitas sesuai dengan tanggungjawab dan perannya dalam perusahan. Indikator untuk mengukur 
kinerja pegawai menurut (Bangun, 2012) antara lain kuantitas, kualitas, ketepatan waktu, kehadiran, dan kemampuan kerjasama.

\subsection{Teknik Pengujian Hipotesis dan Analisis Data}

Teknik analisis yang digunakan dalam penelitian ini adalah analisis jalur.
Analisis jalur digunakan untuk mengetahui hubungan sebab akibat dan untu mengetahui hubungan langsung maupun tidak langsung dari beberapa variabel penyebab (eksogen) terhadap variabel akibat (endogen).

\section{HASIL PENELITIAN DAN PEMBAHASAN}

\subsection{Pengaruh Kepemimpinan Transformasional Terhadap Motivasi Kerja}

Tabel 1. Rekapitulasi Hasil Sub Struktur 1 : Kepemimpinan Transformasional Terhadap Motivasi Kerja

\begin{tabular}{|l|c|c|c|c|}
\hline \multicolumn{1}{|c|}{ Variabel } & $\begin{array}{c}\text { Standardized } \\
\text { Coefficients }\end{array}$ & $\begin{array}{c}\mathrm{t} \\
\text { hitung }\end{array}$ & Sig. & Keterangan \\
\hline $\begin{array}{l}\text { Kepemimpinan } \\
\text { Transformasional }\end{array}$ & 0.774 & 13.332 & 0.000 & Signifikan \\
\hline $\mathrm{R}^{2}: 0.599$ & & & & \\
\hline
\end{tabular}

Sumber : Data primer diolah, 2017.

Keterangan : variabel endogen adalah motivasi kerja

Berdasarkan Tabel 1. dapat Nilai R Square variabel kepemimpinan dijelaskan terdapat pengaruh yang transformasional terhadap motivasi kerja signifikan kepemimpinan transformasional terhadap motivasi kerja yang sebesar 0.599 menunjukkan bahwa kemampuan variabel kepemimpinan ditunjukkan oleh nilai signifikansi 0.000 transformasional dalam mempengaruhi lebih kecil dari nilai $(\alpha=0.05)$ dan nilai motivasi kerja sebesar 59.9\%. Penerapan koefisien beta sebesar 0.774 yang berarti bahwa semakin baik penerapan kepemimpinan transformasional sebesar $1 \%$ maka akan semakin meningkatkan motivasi kerja pegawai sebesar $77.4 \%$. kepemimpinan transformasional yang baik dapat lebih memotivasi pegawai untuk berbuat lebih baik dari yang seharusnya dilakukan oleh pegawai sesuai tuntutan pekerjaan. 
Pemimpin yang menerapkan kepemimpinan transformasional akan membuat pegawai nyaman bekerja dengannya sehingga menstimulus pegawai untuk lebih kreatif dalam bekerja dan dapat memotivasi pegawai yang menjadi bawahannya.

\subsection{Pengaruh Kepemimpinan Transformasional dan Motivasi Kerja Terhadap Kinerja Pegawai}

Tabel 2. Rekapitulasi Hasil Sub Struktur $2: \mathrm{X}_{1}$ dan $\mathrm{Y}_{1}$ terhadap $\mathrm{Y}_{2}$

\begin{tabular}{|l|c|c|c|c|}
\hline \multicolumn{1}{|c|}{ Variabel } & $\begin{array}{c}\text { Standardized } \\
\text { Coefficients }\end{array}$ & t hitung & Sig. & Keterangan \\
\hline $\begin{array}{l}\text { Kepemimpinan } \\
\begin{array}{l}\text { Transformasional } \\
\left(\mathrm{X}_{1}\right)\end{array}\end{array}$ & 0.319 & 3.566 & 0.001 & Signifikan \\
\hline $\begin{array}{l}\text { Motivasi Kerja } \\
\left(\mathrm{Y}_{1}\right)\end{array}$ & 0.514 & 5.743 & 0.000 & Signifikan \\
\hline $\mathrm{R}^{2}: 0.621$ & & & & \\
\hline
\end{tabular}

Sumber : Data primer diolah, 2017.

Keterangan : variabel endogen adalah kinerja pegawai $\left(\mathrm{Y}_{2}\right)$

a. Pengaruh

\section{Transformasional}

Kepemimpinan

\section{Kinerja Pegawai}

Berdasarkan tabel 2 dapat dijelaskan bahwa kepemimpinan transformasional mempunyai pengaruh yang signifikan terhadap kinerja pegawai yang ditunjukkan oleh nilai signifikansi 0.001 lebih kecil dari nilai $(\alpha=0.05)$. Semakin baik penerapan kepemimpinan transformasional sebesar $1 \%$ maka akan dapat meningkatkan kinerja pegawai sebesar 0.319 atau $31.9 \%$. Hasil temuan dalam penelitian ini mengindikasikan bahwa kepemimpinan transformasional yang diterapkan oleh pimpinan PT.MNC Skyvision Tbk. Cabang Surabaya dapat mempengaruhi pegawai untuk lebih dapat berbuat atau berusaha sehingga dapat berpengaruh terhadap peningkatan kinerja pegawai yang pada akhirnya bermanfaat dalam rangka mencapai tujuan organisasi.

Menurut Robbins dan Judge (2014:90), kepemimpinan transformasional mampu membuat pegawai menjadi lebih fokus dalam bekerja. Ini akan membuat pegawai menyadari pentingnya hasil akhir sebuah pekerjaan, mendorong bawahan agar pada saat bekerja lebih mendahulukan kepentingan pekerjaan dan perusahaan dibandingkan kepentingan pribadi, dan mengaktifkan higher-order need mereka. 
b. Pengaruh Motivasi Kerja untuk menyelesaika pekerjaannya

\section{Terhadap Kinerja Pegawai}

Berdasarkan tabel 2 dapat dijelaskan bahwa motivasi kerja mempunyai pengaruh yang signifikan terhadap kinerja pegawai yang ditunjukkan oleh nilai signifikansi lebih kecil dari nilai ( $\alpha$ $=0.05)$. Motivasi kerja pegawai yang meningkat sebesar $1 \%$ maka akan dapat meningkatkan kinerja pegawai sebesar 0.514 atau $51.4 \%$. Motivasi kerja adalah kunci penting dalam meningkatkan efektivitas kerja. Pegawai dengan motivasi kerja yang tinggi akan dengan suka rela dan berusaha sekuat tenaga dengan baik. Oleh karena itu pemberian motivasi kerja yang sesuai kebutuhan utama pegawai seperti yang dikemukakan oleh Clayton Adelfer melalui teori ERG (Existence Needs, Related Needs, Growth Needs) menjadi hal yang penting yang harus diperhatikan oleh pimpinan untuk menghasilkan kinerja pegawai yang optimal.

\subsection{Hasil Uji Analisis Jalur}

Hasil analisis jalur menghasilkan model yang dapat digambarkan sebagai berikut :

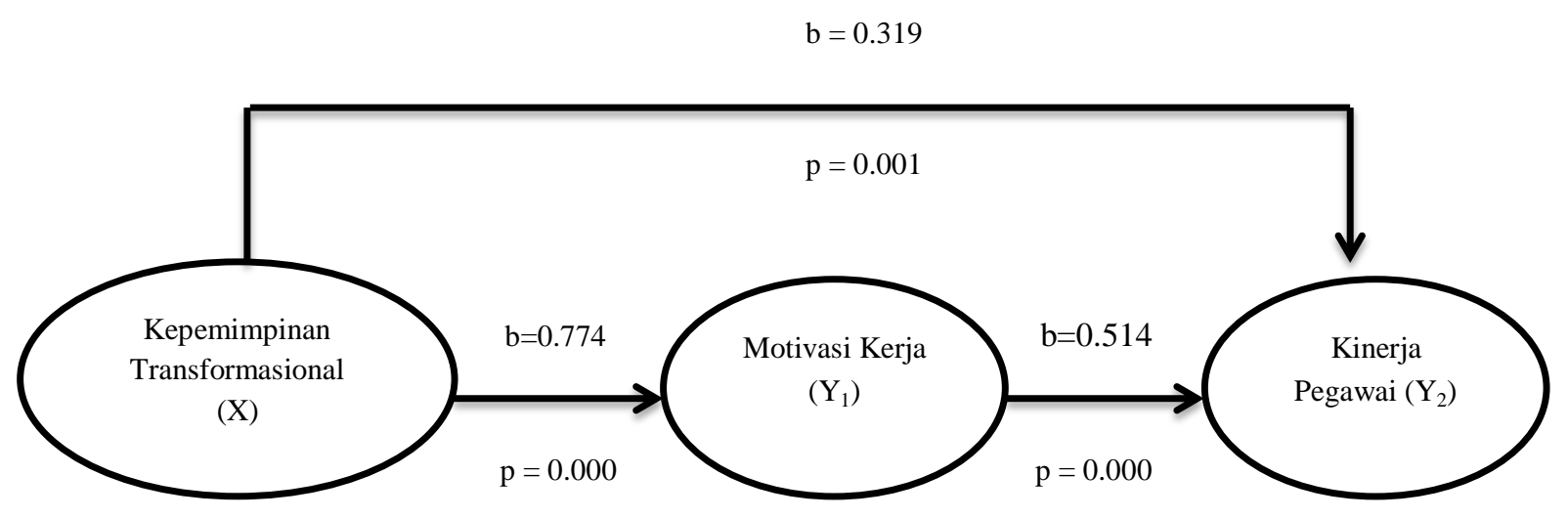

Gambar 1. Model Penelitian

Sumber : Data primer diolah, tahun 2017 
Tabel 3. Hasil Uji Analisis Jalur

\begin{tabular}{|c|c|c|c|c|}
\hline No & Jalur & Langsung & $\begin{array}{c}\text { Tidak } \\
\text { Langsung }\end{array}$ & Total \\
\hline 1 & $\mathrm{X}-\mathrm{Y} 1$ & 0.774 & - & 0.774 \\
\hline 2 & $\mathrm{X}-\mathrm{Y} 2$ & 0.319 & - & 0.319 \\
\hline 3 & $\mathrm{Y} 1-\mathrm{Y} 2$ & 0.514 & - & 0.514 \\
\hline 4 & $\mathrm{X}-\mathrm{Y} 1-\mathrm{Y} 2$ & 0.319 & $\begin{array}{c}\text { Melalui } \\
\text { Motivasi } \\
\text { Kerja } 0.774 \\
\text { x } 0.514= \\
0.398\end{array}$ & 0.717 \\
\hline
\end{tabular}

Sumber : Data primer diolah, tahun 2017

Berdasarkan Tabel 3. diketahui bahwa kepemimpinan transformasional mempunyai pengaruh tidak langsung terhadap kinerja pegawai melalui motivasi kerja yang lebih besar yakni sebesar 0.398, dibandingkan pengaruh langsung tanpa melalui motivasi kerja yakni sebesar 0.319. Hal ini berarti penerapan kepemimpinan transformasional yang baik akan mampu meningkatkan motivasi kerja pegawai sehingga dampaknya adalah akan terjadi peningkatan kinerja pegawai yang tentunya sangat diharapkan oleh perusahaan.

\section{PENUTUP}

\subsection{Simpulan}

Hasil penelitian menunjukkan bahwa :

1. Kepemimpinan transformasional berpengaruh signifikan terhadap motivasi kerja, yang berarti bahwa kepemimpinan transformasional yang diterapkan dengan baik membuat hubungan pimpinan dan pegawai semakin harmonis sehingga dapat meningkatkan motivasi pegawai dalam bekerja.

2. Kepemimpinan transformasional berpengaruh signifikan terhadap kinerja pegawai, yang berarti bahwa kepemimpinan transformasional yang diterapkan dengan baik di dalam perusahaan membuat kinerja pegawai semakin meningkat.

3. Motivasi kerja berpengaruh signifikan terhadap kinerja pegawai, yang berarti bahwa karyawan yang memiliki motivasi yang tinggi dalam bekerja akan dapat menghasilkan kinerja yang bagus pula.

4. Kepemimpinan transformasional berpengaruh signifikan terhadap kinerja pegawai melalui motivasi kerja, yang berarti bahwa semakin 
baik kepemimpinan transformasional yang diterapkan dalam perusahaan dapat memotivasi karyawan untuk bekerja lebih baik sehingga menghasilkan kinerja yang semakin meningkat.

\subsection{Saran}

1. Diharapkan agar penerapan kepemimpinan transformasional tetap dijalankan dengan baik dan ditingkatkan sehingga terjalin hubungan yang harmonis antara pimpinan dan pegawai yang dapat meningkatkan motivasi kerja pegawai sehingga nantinya perusahaan akan mendapatkan hasil berupa peningkatan kinerja pegawai.

2. Bagi peneliti selanjutnya dapat mengembangkan penelitian ini dengan meneliti faktor lain yang dapat meningkatkan motivasi kerja dan kinerja pegawai seperti variabel lingkungan kerja dan budaya organisasi.

\section{DAFTAR PUSTAKA}

Ariesta, Riza. 2014. Analisis Pengaruh Gaya Kepemimpinan Transformasional dan Gaya Kepemimpinan Transaksional
Terhadap Kinerja Karyawan.

Skripsi.

http://eprints.undip.ac.id/44632/1/0 5_ARIESTA.pdf.

Bangun, W. 2012. Manajemen Sumber Daya Manusia. Jakarta: Erlangga.

Bass, B.M. 1985. Leadership and Performance Beyond Expectation. New York : Academic Press.

Budiharjo. 2015. Panduan Praktis Penilaian Kinerja Karyawan. Jakarta : Raih Asa Sukses.

Chishti, Saeed ul Hassan, dkk. 2010. Impact of Participative Management on Employee Job Satisfaction in Pakistan. Jurnal Volume 10: 12 Desember 2010 (ISSN 1930-2940). Hlm.12-13.

Colquitt, Jason A., Jeffrey A. LePine, and Michael J. Wesson. 2011. Organizational Behavior. New York : McGraw-Hill.

Ghozali, Imam. 2009. Aplikasi Analisis Multivariat Dengan Program SPSS. Semarang : Badang Penerbit Universitas Diponegoro.

Ghozali, Imam. 2013. Aplikasi Analisis Multivariate dengan Program IBM SPSS 21 Update PLS Regresi. Semarang: Badan Penerbit Universitas Diponegoro. 
Husein, Umar. 2010. Riset Pemasaran dan Bisnis. Jakarta : Gramedia Pustaka Utama.

Ismail, Azman; Mohammed, Hasan. A; Sulaiman, Ahmad. Z; Mohammad, Hamran. M; Yusuf, Munirah. H. 2011. An Empirical Study of The Relationship Between Transformational Leadership, Empowerment and Organization Commitment. Business and Economics Research Journal.

Jackson. Schuler. Werner. 2010. Pengelolaan Sumber Daya Manusia. Jakarta: Salemba Empat.

Kharis, Indra. 2015. Pengaruh Gaya Kepemimpinan Transformasional Terhadap Kinerja Karyawan Dengan Motivasi Sebagai Variabel Intervening (Studi Pada Karyawan Bank Jatim Cabang Malang). Jurnal Administrasi Bisnis. Vol. 3 No.1. hal : 1-9.

Kiptiyah, Marisatul. 2015. Pengaruh Gaya Kepemimpinan Transformasional dan Kompensasi Terhadap Kinerja Karyawan PT. Madu Baru PG/PS Madukismo. Skripsi.

http://eprints.uny.ac.id/23738/1/M arisatulKiptiyah.pdf.
Kreitner, Robert and Angelo Kinicki. 2010. Organizational Behavior. New York : McGraw-Hill.

Kurniawan, Albert. 2014. Metode Riset untuk Ekonomi dan Bisnis. Bandung : CV.Alfabeta.

Mangkunegara. Anwar. Prabu. 2013. Manajemen Sumber Daya Manusia Perusahaan. Edisi11.Bandung: Remaja Rosdakarya Mariam, Rani. 2009. Pengaruh Gaya Kepemimpinan dan Budaya Organisasi Terhadap Kinerja Karyawan Melalui Kepuasan Kerja Karyawan Sebagai Variabel Intervening. Tesis. Universitas Diponegoro. Semarang.

Maulizar. Musnadi, Said. Yunus, Mukhlis. 2012. Pengaruh Kepemimpinan Transaksional dan Transformasional Terhadap Kinerja Karyawan Bank Syariah Mandiri Cabang Banda. Jurnal Ilmu Manajemen, 1, 1-13. McShane, Steven L. and Mary Ann Von Glinow. 2010. Organizational Behavior. New York : McGrawHill.

Nimran, Umar. 2012. Perilaku Organisasi. Sidoarjo : Laros. 
Nitisemito, Alex S. 2010. Manajemen Personalia. Jakarta : Ghalia Indonesia.

Noe, R. Hollenbeck, J.R. Gerhart, B.,Wright,P. 2013. Manajemen Sumber Daya Manusia : Mencapai Keunggulan Bersaing. Jakarta : Salemba Empat.

Nurafiah, Fifi. 2012. Pengaruh Gaya Kepemimpinan Transformasional Terhadap Komitmen Organisasional Pada PT. Bank XYZ Tbk CabangTangerang.Skripsi.http://lib .ui.ac.id/file?file=digital/20318969 -S-PDF-Fifi\%20Nurafiah.pdf

Papera, Gamage Dinoka Nimali, Ali Khatibi, Nimal Navaratna dan Karuthan. 2014. "Job Satisfaction And Job Performance Among Factory Employees in Apparel Sector". Journal of Management Sciences \& Education, Vol. 3. No.1. Hal 78-79. Sri Langka : University of Colombo.

Prakoso, R.D., Endang S.A., Ika R. 2014. Pengaruh Lingkungan Kerja Terhadap Motivasi Kerja dan Kinerja Karyawan (Studi Pada Karyawan PT. AXA Financial Indonesia Cabang Malang). Jurnal Administrasi Bisnis. Vol. 14 No.2. hal : 1-10.
Prihantoro, Agung. 2012. Peningkatan Kinerja Sumber Daya Manusia Melalui Motivasi, Disiplin, Lingkungan Kerja, dan Komitmen. Jurnal Value Added. Vol.8, No.2, hal 78-91. http://jurnal.unimus .ac.id.

Repie, Jeane Aneke dan I Gusti Ayu Dewi Adnyani. 2015. Pengaruh Gaya Kepemimpinan Transformasional, Komunikasi dan Kompensasi Finansial Terhadap Kinerja Karyawan. Jurnal Manajemen Vol 4. No.2. hal 556558.

Riani, Asri Laksmi. 2011. Budaya Organisasi. Yogyakarta: Graha Ilmu.

Ritawati, Agustina. 2013. Pengaruh Kepemimpinan Transformasional dan Budaya Organisasi Terhadap Kepuasan Kerja dan Kinerja Karyawan PT. Jamsostek (Persero) Cabang Surabaya. Jurnal Ilmu Ekonomi dan Manajemen. Vol.9 No.1.pp. 82-93.

Rivai, Veithzal dan Ella Jauvani Sagala. 2014. Manajemen Sumber Daya Manusia Untuk Perusahaan; Dari Teori ke Praktik. Edisi 2. Jakarta : Rajagrafindo Persada. 
Robbins. Stephen. P. 2008. Perilaku Organisasi. Jakarta : PT. Indeks Kelompok Gramedia.

Robbins dan Judge. 2014. Perilaku Organisasi. Edisi Dua Belas. Jakarta : Salemba Empat.

Sashkin, Marshall, Molly G. Sashkin. 2011. Prinsip-Prinsip Kepemimpinan. Jakarta : Erlangga.

Sedarmayanti. 2011. Manajemen Sumber Daya Manusia Reformasi Birokrasi dan Manajemen Pegawai Negeri Sipil. Bandung: PT. Refika Aditama.

Sekaran, Uma dan Bougie. 2013. Research Methodes for Business: A Skill Building Approach $6^{\text {th }}$ ed. United Kingdom : John Wiley and Sons.

Siagian, S.P. 2014. Manajemen Sumber Daya Manusia. Jakarta : Bumi Aksara.

Sugiyono. 2015. Metode Penelitian Manajemen. Bandung : $\mathrm{CV}$. Alfabeta.

Sutrisno, E. 2009. Manajemen Sumber Daya Manusia. Jakarta : Kencana.

Wibowo. 2013. Perilaku dalam Organisasi. Jakarta : Rajawali Press.

Wijonarko, Widi, N.2014. Pengaruh Gaya Kepemimpinan Transforma- sional dan Motivasi Kerja Terhadap Kinerja Agen. Skripsi. http://eprints.uny.ac.id/15134/1/SK RIPSI_R.\%20Widi\%20Nugroho.p $\underline{\mathrm{df}}$

Wirawan. 2009. Evaluasi Kinerja Sumber Daya Manusia: Teori Aplikasi dan Penelitian. Jakarta : Salemba Empat. 